\title{
Studies in Asian Nervilia (Orchidaceae) VII: Nervilia kasiensis, a new Lao endemic
}

\author{
S.W. Gale ${ }^{1}$, T. Phaxaysombath ${ }^{2}$
}

Key words

Hysteranthy

Laos

new species

Orchidaceae

species complex

\begin{abstract}
A new species belonging to the terrestrial orchid genus Nervilia is described from Kasi District, Vientiane Province, northern Laos. Referable to the widespread and species-rich N. adolphi/punctata alliance on account of its solitary flower, slender white and violet-marked labellum and glabrous, angular leaf, $N$. kasiensis is morphologically most closely allied to $N$. muratana of southern China and northern Vietnam. As in that species, the flowering and leafing phases overlap, an unusual feature among members of the genus. The new species can be distinguished from N. muratana by its shorter inflorescence, its weakly spreading perianth with beige sepals, its narrower labellum with a central pubescent strip on the epichile, its arched column, and by its faintly tessellated leaf. A morphologica description, line drawing and notes on the species' ecology and conservation status are presented.
\end{abstract}

Published on 12 January 2017

\section{INTRODUCTION}

The Old World terrestrial orchid genus Nervilia continues to grow, with the addition of at least one new species per year for the last five years (Averyanov 2011a, Hsu et al. 2012, Jalal et al. 2012, Gale et al. 2013, 2014, 2015, 2016, Lin \& Chang 2013, Lin 2014). All of these recent discoveries occur in tropical or subtropical Asia, and each is referable to one of a series of species complexes whose ecology and evolution remains only poorly understood. The few molecular and cytological studies carried out to date suggest that small morphological differences within these complexes - even between species inhabiting the same site - can mask significant genetic distances and variation in ploidy level (Gale et al. 2010, 2015, Eum et al. 2011). This suggests the occurrence of considerably more cryptic diversity than presently recognised.

In a cladistic analysis focusing on African members of the genus, Pettersson (1991) circumscribed an alliance of closely related one-flowered species unified by the combination of an elongating fruiting scape, a glabrous, angular leaf and a pubescent column, as epitomised by the African N. adolphi Schltr. and the Indonesian N. punctata (Blume) Makino. The concept of the so-called 'Nervilia adolphi/punctata species alliance' has since been further examined in Asia by Gale et al. (2013, 2015), with the addition of a slender, entire and predominantly white labellum with violet markings as a typical character. The alliance accounts for at least 26 of the approximately 70 species presently accepted in the genus, with representatives distributed throughout most of the generic range, from sub-Saharan Africa, through tropical, subtropical and warm temperate Asia to the Southwest Pacific Islands. Most occur in deep shade as elements of the forest understorey (Gale et al. 2015).

As for the genus as a whole, members of the alliance exhibit a hysteranthous annual cycle in which the solitary scape emerges

\footnotetext{
Kadoorie Farm and Botanic Garden, Lam Kam Road, Tai Po, New Territories, Hong Kong;

corresponding author e-mail: stephangale@kfbg.org.

2 Biodiversity and Ecology Institute, Ministry of Science and Technology,

Vientiane, Laos PDR; e-mail: pthatsaphone@hotmail.com.
}

at the onset of the growing season, followed by the single, deciduous leaf once the flower has either withered or fructified (Pridgeon et al. 2005, Gale et al. 2006). This temporal separation of the flowering and leafing phases, as well as the seasonal dormancy that follows senescence of the leaf at the end of the annual growth cycle, has been interpreted as an adaptation to a strong wet/dry seasonality (Pettersson 1991), with the few recorded exceptions to this characteristic pattern tending to occur in moister habitats or regions with a less marked transition between dry and wet seasons. Thus overlapping reproductive and photosynthetic phases have been noted for $N$. punctata in lowland evergreen forest in Java (Backer \& Bakhuizen van den Brink 1968), for N. borneense (J.J.Sm.) Schltr. in mossy montane forest in East Malaysia (S. Gale pers. observ., voucher: A. Lamb 2089/2011, SAN) and for N. muratana S.W.Gale \& S.K.Wu in humid broadleaved forest in South China and northern Vietnam (Gale \& Wu 2008, Averyanov 2011b); all three of these species belong to the $N$. adolphi/punctata alliance.

To date, only five species of Nervilia have been recorded from Laos (Schuiteman et al. 2008, Gale et al. 2016). Given that 11 species are known from Thailand (Gale \& Watthana 2014, Gale et al. 2016) and eight are known from Vietnam (Averyanov \& Averyanova 2003, Averyanov 2011a, b, Gale et al. 2016), this is likely to be an underestimate due in part to insufficient botanical exploration (Newman et al. 2007), as well as to the inconspicuous and ephemeral nature of the plants themselves (Gale et al. 2014) and the potential presence of cryptic taxa (Gale et al. 2015). During a recent survey of remnant primary forest fragments in the north of the country, the present authors discovered an unidentified member of the $N$. adolphi/ punctata alliance that was striking for its unusually large, faintly tessellated leaf. Subsequent analysis of plants that flowered in cultivation confirmed that they represent an undescribed species morphologically allied to $N$. muratana. Reinforcing this affiliation, seasonal dormancy was absent, with the leaf undergoing senescence only after emergence of the flower in the following growth cycle (Fig. 1b). 


\section{DESCRIPTION}

Nervilia kasiensis S.W.Gale \& Phaxaysombath, sp. nov. Fig. 1, 2, 3

This new species most closely resembles $N$. muratana S.W.Gale \& S.K.Wu in the outline of its labellum, in the shape of its leaf and in its non-hysteranthous growth habit. However, N. kasiensis is distinguished from $N$. muratana by its much shorter inflorescence (up to $4.3 \mathrm{~cm}$ in the former vs $6.5-10.0 \mathrm{~cm}$ in the latter), its weakly spreading perianth (vs widely spreading in the latter) with beige sepals (vs white in the latter), its narrower labellum (up to $6.4 \mathrm{~mm}$ wide in the former vs 9-12 $\mathrm{mm}$ wide in the latter) with a central pubescent strip on the epichile (vs shortly and sparsely hairy along the main veins in the latter), its arched column (vs straight in the latter), and by its tessellated leaf (vs uniformly dark green in the latter). - Type: Gale \& Phaxaysombath HNL-KFBG 537b (holotype HNL, flowered in cultivation from Gale \& Phaxaysombath HNL-KFBG 537a), ex cult. Biotechnology \& Ecology Institute, Ministry of Science \& Technology, Vientiane, Laos, 11 Mar. 2016; Gale \&
Phaxaysombath HNL-KFBG 537a (paratype HNL, leaf), Khoun Lang Cave, Kasi District, Vientiane Province, Laos, 29 Nov. 2015.

Etymology. Named after Kasi District, northern Laos, in which this species was discovered.

Glabrous terrestrial herb up to $12 \mathrm{~cm}$ tall. Tuber cream-white, ovoid-fusiform, $1.1-1.8 \mathrm{~cm}$ long, $0.6-1.2 \mathrm{~cm}$ wide, $3-4$-noded, bearing a few stout, wiry, minutely hairy roots up to $1.3 \mathrm{~cm}$ long at the nodes. Subterranean stem emerging from apical or intermediate node of tuber, whitish brown, $2.1-6.7 \mathrm{~cm}$ long, 1.8-2.6 mm diam, many-noded, producing 2-3 segmented lateral runners up to c. $5.0 \mathrm{~cm}$ in length that each give rise to a daughter tuber at the apex. Petiole-like stalk light green, erect, (3.1-)8.5-10.2 cm long, 2.8-3.0 mm diam, sulcate, bearing 1 brown, fibrous, loosely sheathing cataphyll $1.9-2.3 \mathrm{~cm}$ long at base. Leaf blade dark green with bands of faint, iridescent silver-
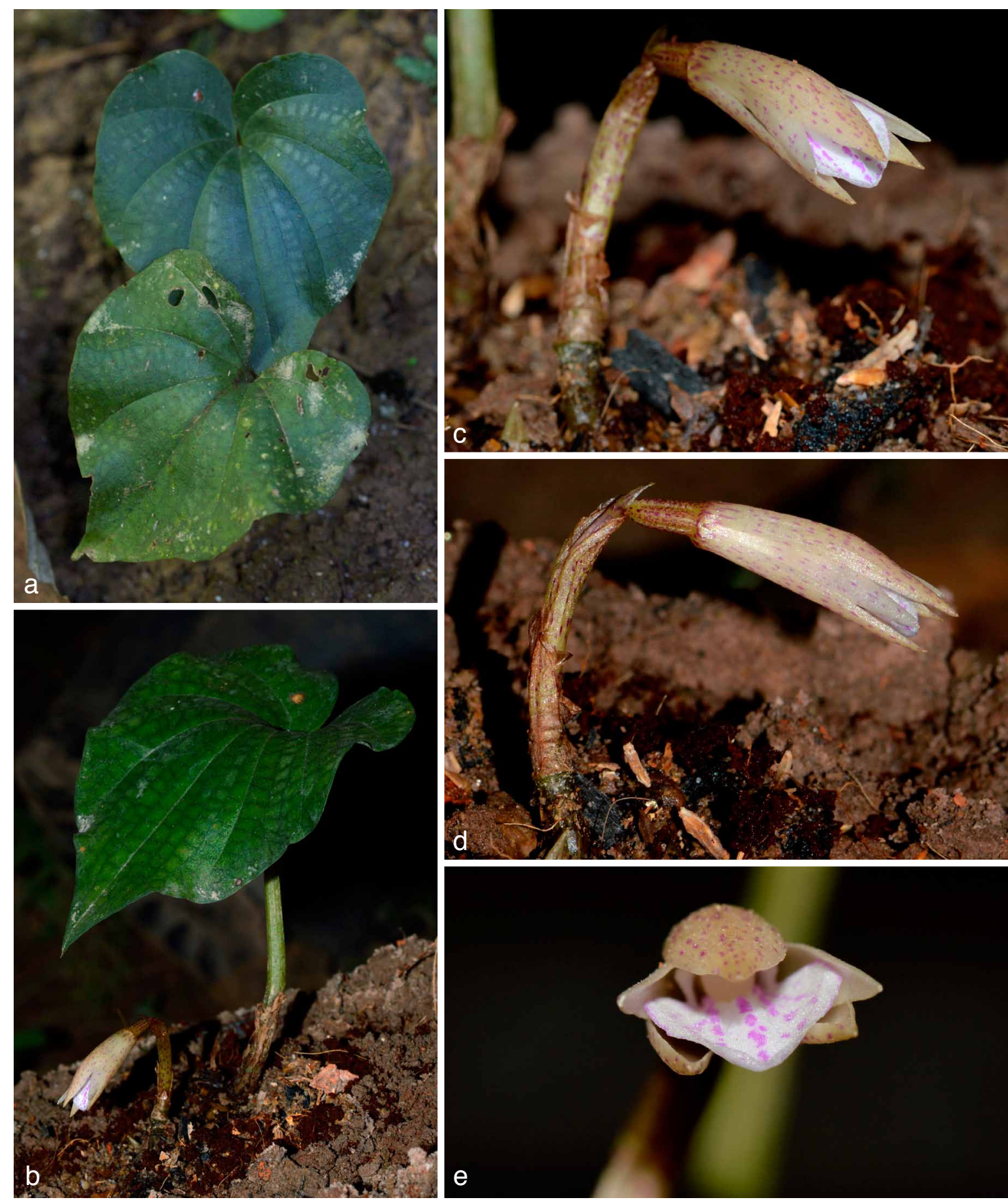

Fig. 1 Nervilia kasiensis S.W.Gale \& Phaxaysombath. a. Plants in leaf at the type locality in northwest Laos showing the faint silver-grey mottling on the adaxial surface; b. plant in flower showing the non-hysteranthous growth habit; c. close-up of inflorescence; d. lateral view of flower showing slightly saccate base of the lateral sepals; e. front view of flower showing the weakly spreading perianth. 

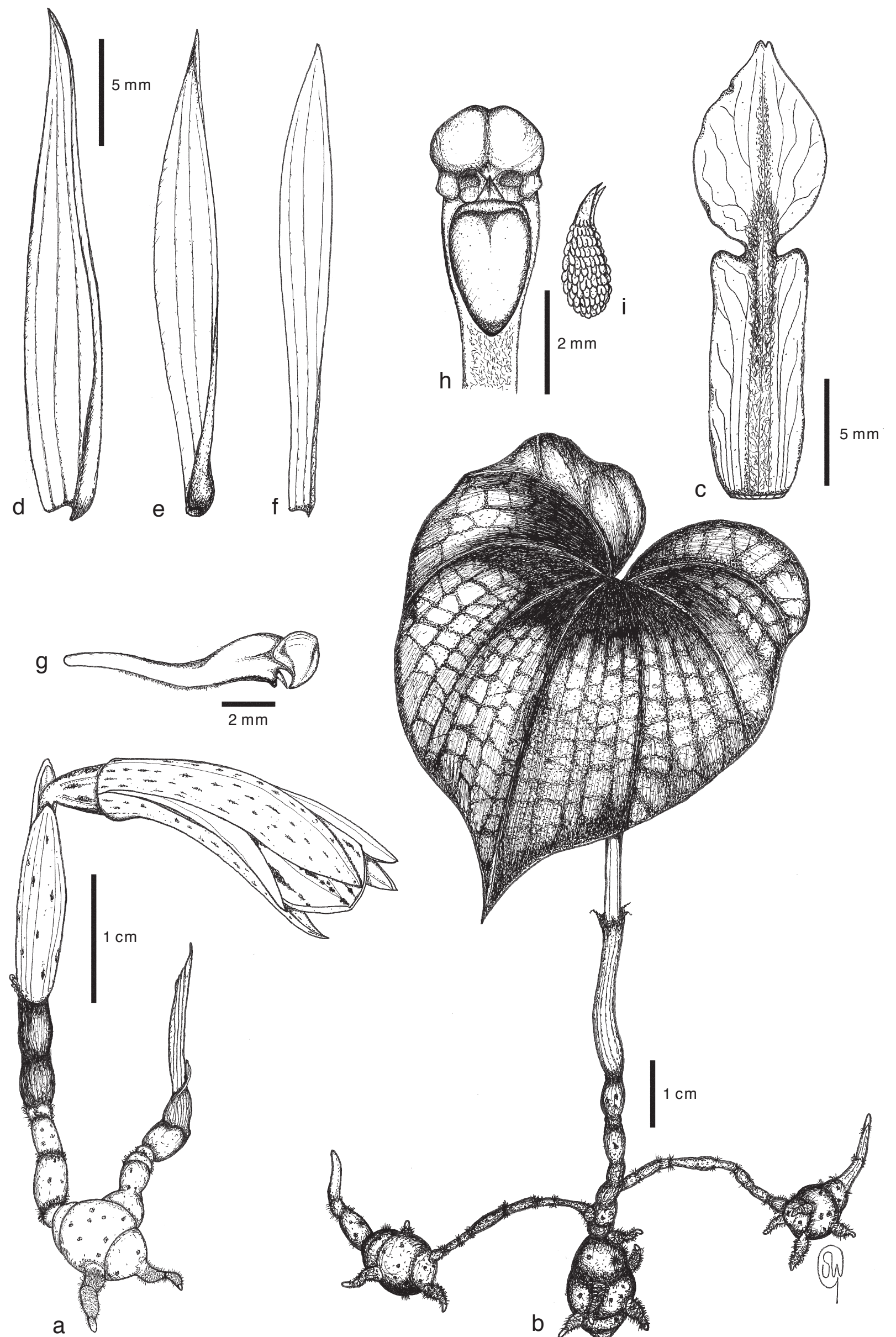
grey tessellation in between the main veins, held well above ground level, cordate-polygonal, with 7 main veins diverging palmately from the origin of the petiole-like stalk, slightly lobed at the tips of the main veins in some individuals, (4.5-)7.7-8.9 $\mathrm{cm}$ long, (4.2-)7.2-8.0 cm wide, deeply cordate at base, the basal lobes rounded, not overlapping, margin flat, apex acute. Inflorescence emerging while the plant is in leaf, erect, terminal, warty at base near junction with subterranean stem, terete above, $2.5-4.3 \mathrm{~cm}$ long to origin of floral bract, $2.0-2.2 \mathrm{~mm}$ diam, olive green flushed brown, bearing 1 short papery sterile bract at base and 1 sheathing cataphyll above; cataphyll olive green flushed brown with irregular purple blotches, 1.8-2.8 $\mathrm{cm}$ long, enclosing the base of the floral bract, apex acute; floral bract olive green with irregular purple blotches, narrowly elliptic, 4.8-5.5 mm long, 1.4-1.6 $\mathrm{mm}$ wide, exceeding the pedicel, apex acute. Flower solitary, resupinate, nodding, perianth not spreading widely; pedicel concealed within the base of the floral bract, up to $2.0 \mathrm{~mm}$ long; ovary narrowly conical, 4.9-5.2 mm long, c. $2.5 \mathrm{~mm}$ diam, olive green with irregular purple blotches; sepals and petals similar, outer surfaces cream-beige with irregular pink-violet flecks, glossy white inside, narrowly elliptic-lanceolate, acuminate; dorsal sepal 22.4-26.8 $\mathrm{mm}$ long, 3.5-4.2 mm wide, 5-veined; lateral sepals slightly oblique, slightly inflated and slightly saccate at base, 21.8-24.6 $\mathrm{mm}$ long, $2.8-3.5 \mathrm{~mm}$ wide, 3-veined; petals slightly oblique, 21.0-23.5 mm long, $1.8-2.8 \mathrm{~mm}$ wide, 3-veined; labellum white with irregular pink-violet flecks and blotches, not spurred but slightly concave at base, narrowly obovate-spathulate, 20.7-21.5 mm long, divided above the middle by a narrow waist into a hypochile and epichile; hypochile oblong, 11.2-12.0 mm long, 3.5-4.2 $\mathrm{mm}$ wide, lateral margins raised and embracing the column, terminating in a pair of short, ovate, obtuse auricles up to $0.4 \mathrm{~mm}$ long; epichile ovate-orbicular, 9.5-9.8 $\mathrm{mm}$ long, 5.9-6.4 mm wide, apex acute; disk bearing a central lanate

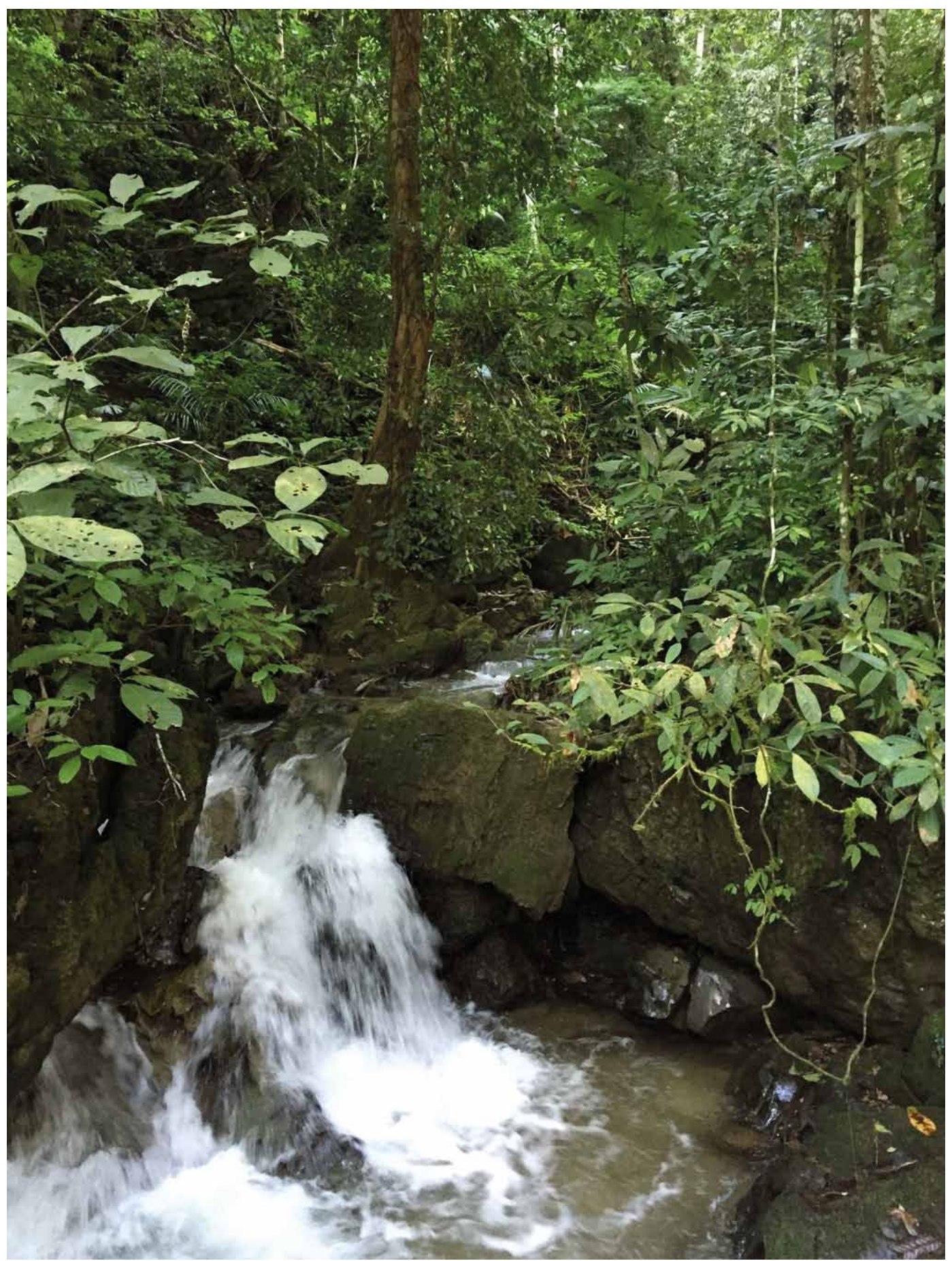

Fig. 3 Primary, moist evergreen forest at the type locality in Kasi District, Vientiane Province, northwest Laos. 
band that divides in 2 below the auricles and then merges again at the base of the epichile to form a raised pubescent strip that terminates within $1.5 \mathrm{~mm}$ of the apex, shortly papillate elsewhere on the epichile. Column white, slender, clavate, arched towards the apex, 10.2-11.5 mm long, with a patch of short hairs below the stigma; anther cap helmet-shaped, c. $1.8 \mathrm{~mm}$ long; pollinia enclosed behind the stigma, 2.6-2.8 mm long; stigma shield-shaped, slightly concave; rostellum forming a prominent ridge along the apex of the stigma.

Distribution - At present known only from the type collection, which comes from fragmented primary hill forest in northern Laos (Fig. 3). Its discovery in similar habitats elsewhere in Laos as well as in neighbouring parts of Thailand and Vietnam might be expected, although primary forest in the region continues to dwindle rapidly.

Ecology - Nervilia kasiensis is an understorey herb that grows in shade in deep organic soils in moist, evergreen hill forest over limestone at c. $750 \mathrm{~m}$ altitude. The flowering shoot emerges in March, while its tuber is still connected by a runner to the previous year's leafy shoot. The old leaf withers and a new leaf emerges from a separate runner after anthesis. Multiple runners are produced both from nodes of the tuber itself and from the subterranean stem of leafy shoots. The presence of a prominent rostellum at the apex of the stigma (Fig. $2 \mathrm{~h}$ ) suggests that N. kasiensis is outcrossing (cf. Gale 2007).

Conservation status - Only a small population of fewer than ten emergent shoots was found at the type locality. The availability of suitable habitat throughout the Khoun Lang Nature Reserve offers hope that more plants occur nearby. However, on-going destruction of primary moist broadleaved forest in northern Laos, as well as in neighbouring parts of Indochina, indicates that this apparently restricted and rare species is under considerable threat due to habitat loss. Pending surveys to better gauge its distribution and abundance, $N$. kasiensis is for now considered Data Deficient (DD; IUCN 2012).

Note - On account of its glabrous, angular leaf and the narrow, white and violet-marked labellum of its single flower, $N$. kasiensis is immediately recognisable as a member of the $N$. adolphi/punctata alliance. In addition to the characters noted in the diagnosis that differentiate it from N. muratana, its closest morphological ally, $N$. kasiensis is also distinguished by its relatively broader tepals as compared to those of that species. In its non-spreading perianth, the slightly concave base of its lip and the rounded hypochile auricles, $N$. kasiensis is also similar to $N$. alishanensis T.C.Hsu, S.W.Chung \& C.M.Kuo, a species of Taiwan and Hainan Province in southeast China (Hsu et al. 2012, Gale et al. 2015). However, overall dimensions of the leaf and flower parts are otherwise markedly different, added to which $N$. alishanensis lacks a functional rostellum and is reported to be self-pollinating (Hsieh et al. 2013).

Acknowledgements We thank Somsanith Bouamanivong, Ratsamy Phanthavong, Khamsay Soumounthong and Gunter Fischer for assistance in the planning of field work in Kasi District. We are also grateful to Pankaj Kumar for constructive discussions on the orchid flora of Laos.

\section{REFERENCES}

Averyanov L. 2011a. Nervilia gracilis - A new orchid species from northern Vietnam. Taiwania 56: 50-53.

Averyanov L. 2011b. The orchids of Vietnam illustrated survey. Part 3. Subfamily Epidendroideae (primitive tribes - Neottieae, Vanilleae, Gastrodieae, Nervilieae). Turczaninowia 14, 2: 15-100.

Averyanov LV, Averyanova AL. 2003. Updated checklist of the Orchids of Vietnam. Vietnam National University Publishing House, Hanoi.

Backer CA, Bakhuizen van den Brink RC. 1968. Flora of Java Volume III. Noordhoff, Groningen.

Eum SM, Gale S, Yukawa T, et al. 2011. Phylogenetic and conservation status of the endangered terrestrial orchid Nervilia nipponica (Orchidacae) in Korea. Biochemical Systematics and Ecology 39: 635-642.

Gale S. 2007. Autogamous seed set in a critically endangered orchid in Japan: pollination studies for the conservation of Nervilia nipponica. Plant Systematics and Evolution 268: 59-73.

Gale SW, Li J, Kinoshita A, et al. 2015. Studies in Asian Nervilia (Orchidaceae) V: N. futago, a cryptic new species from southwest Japan confirmed by morphological, cytological and molecular analyses. Systematic Botany 40: 413-425.

Gale SW, Maeda A, Chen C-I, et al. 2010. Inter-specific relationships and hierarchical spatial genetic structuring in Nervilia nipponica, an endangered orchid in Japan. Journal of Plant Research 123: 625-637.

Gale SW, Maeda A, Kuroiwa N. 2006. Observations on the phenology and reproductive success of the critically endangered Nervilia nipponica (Orchidaceae) in Kochi Prefecture, Japan. Acta Phytotaxonomica et Geobotanica 57: 81-93.

Gale SW, Rueangruea S, Suddee S. 2014. Studies in Asian Nervilia (Nerviliae, Epidendroideae, Orchidaceae) IV: N. umphangensis, a new species from the Thai-Myanmar border. Phytotaxa 166: 139-144.

Gale SW, Schuiteman A, Watthana S, et al. 2016. Studies in Asian Nervilia (Nervilieae, Epidendroideae, Orchidaceae) VI: N. mekongensis, a new species from Thailand, Cambodia, Laos and Vietnam. Phytotaxa 247: 267-273.

Gale SW, Suddee S, Watthana S. 2013. Studies in Asian Nervilia (Orchidaceae) III: N. khaoyaica, a new species from eastern Thailand. Kew Bulletin 68: 331-335.

Gale SW, Watthana S. 2014. Nervilia. In: Santisuk T, Balslev H (eds), Flora of Thailand Volume 12, 2: 553-569. Forest Herbarium, Department of National Parks, Wildlife and Plant Conservation, Bangkok.

Gale SW, Wu SK. 2008. Studies in Asian Nervilia (Orchidaceae) II: N. muratana, a new species from southern Yunnan, China. Makinoa new series 7: $79-86$.

Hsieh S-I, Gale SW, Lee C-T, et al. 2013. Nervilia brevilobata sp. nov. (Orchidaceae) from Taiwan and Hainan. Nordic Journal of Botany 31: 403-407.

Hsu T-C, Chung S-W, Kuo C-M. 2012. Supplements to the orchid flora of Taiwan (VI). Taiwania 57: 271-277.

IUCN. 2012. IUCN red list categories and criteria: Version 3.1. Second edition. Species Survival Commission, IUCN, Gland \& Cambridge.

Jalal JS, Kumar P, Rawat GS. 2012. Nervilia pangteyiana: a new terrestrial orchid from western Himalaya, India. Nordic Journal of Botany 30: 407-411.

Lin T-P. 2014. Newly discovered native orchids of Taiwan (VII). Taiwania 59: 360-367.

Lin T-P, Chang Y-N. 2013. Newly discovered native orchids of Taiwan (VI). Taiwania 58: 257-267.

Newman M, Ketphanh S, Svengsuksa B, et al. 2007. A checklist of the vascular plants of Lao PDR. Royal Botanic Garden, Edinburgh.

Pettersson B. 1991. The genus Nervilia (Orchidaceae) in Africa and the Arabian Peninsula. Orchid Monographs Volume 5. Rijksherbarium/Hortus Botanicus, Leiden.

Pridgeon AM, Cribb PJ, Chase MW, et al. (eds). 2005. Genera Orchidacearum Volume 4. Epidendroideae (Part One). Oxford University Press, Oxford.

Schuiteman A, Bonnet P, Svengsuksa B, et al. 2008. An annotated checklist of the Orchidaceae of Laos. Nordic Journal of Botany 26: 257-316. 